\title{
Note
}

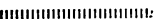

\section{Increase of the Yield of DNA from Barley Nuclei in Ethylene Glycol by $\boldsymbol{\gamma}$-Irradiation ${ }^{\dagger}$}

\author{
Tadao NAITO and Hikoyuki YAMAGUCHI* \\ Faculty of Agriculture, Meiji University \\ 1-1-1, Higashimita, Tama-ku, Kawasaki-shi 214 \\ *Faculty of Agriculture, University of Tokyo \\ 1-1-1, Yayoi, Bunkyo-ku, Tokyo 113 \\ Received March 11, 1983
}

\begin{abstract}
After $\gamma$-irradiating the nuclei isolated from dry seed-embryo of barley in the presence of varying concentrations of ethylene glycol, macromolecular DNA (deoxyribonucleic acid) was extracted from them. The yields of DNA was determined by the 2 methods. The both method of determination on DNA showed a similar tendency; the higher the exposed dose and the concentration of ethylene glycol, the better the yields.
\end{abstract}

Key Words: barley, nuclei, ethylene glycol, $\gamma$-irradiation, macromolecular deoxyribonucleic acid

\section{Introduction}

It is now generally accepted that the radiosensitive target in the cell resides in the nucleus and DNA (or possibly nucleoprotein) is the most sensitive molecule within the nucleus. For investigating the biological effects induced by ionizing radiations to a cell nucleus, it is important to perform in such an experimental condition that no interaction between nucleus and cytoplasm occurs during and after irradiation. On the other hand, ethylene glycol is wellknown as a radical scavenger, and in cultured mammalian cells the presence of high concentration of ethylene glycol eliminates the indirect action of ionizing radiations for capturing radicals produced by irradiation ${ }^{1)}$. After, in the presence of ethylene glycol, therefore, irradiating the nuclei isolated from embryos of barley dry seed, we extracted DNA molecules from the irradiated nuclei. This report communicates that the yields of macromolecular DNA from the nuclei increase with increasing doses.

†エチレングリコール存在下での $\gamma$ 線照射による大 麦種子胚 DNA の収量增加。内藤忠雄, 山口彦 之*; 明治大学農学部, 214 川崎市多摩区東三田11-1, *東京大学農学部, 113 東京都文京区弥生1$1-1$ 。

\section{Materials and Methods}

Cell nuclei were isolated from dry seeds of barley (cultivar. Fuji-2-jyo I). The methods of isolation was practiced as shown in Fig. 1. In the presence of ethylene glycol, nuclei in polyethylene tube were $\gamma$-irradiated with $0,150,300$ Gy $(0,15,30 \mathrm{krad})$ at the dose rate of $5 \mathrm{~Gy}$

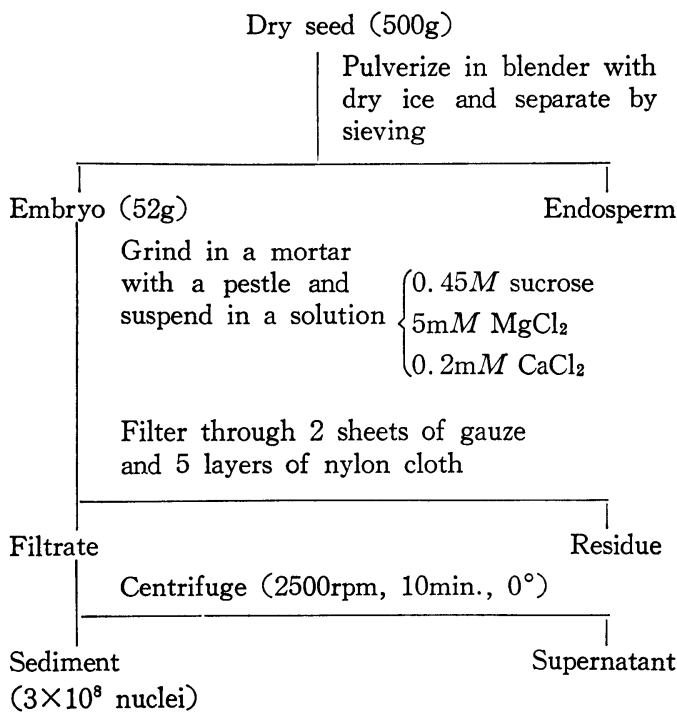

Fig. 1 Procedure of isolation of nuclei from dry seed-embryo in barley. 


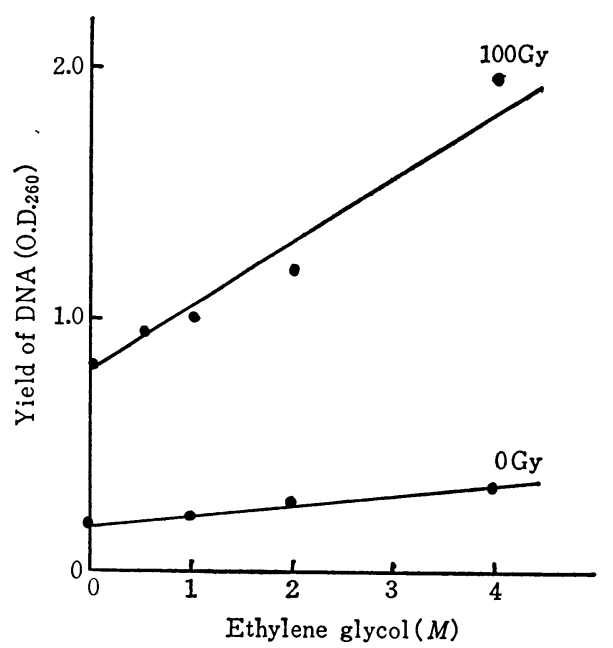

Fig. 2 The yield of macromolecular DNA from $\gamma$-irradiated barley nuclei in the presence of ethylene glycol.

$(1 \mathrm{~Gy}=100 \mathrm{rad})$

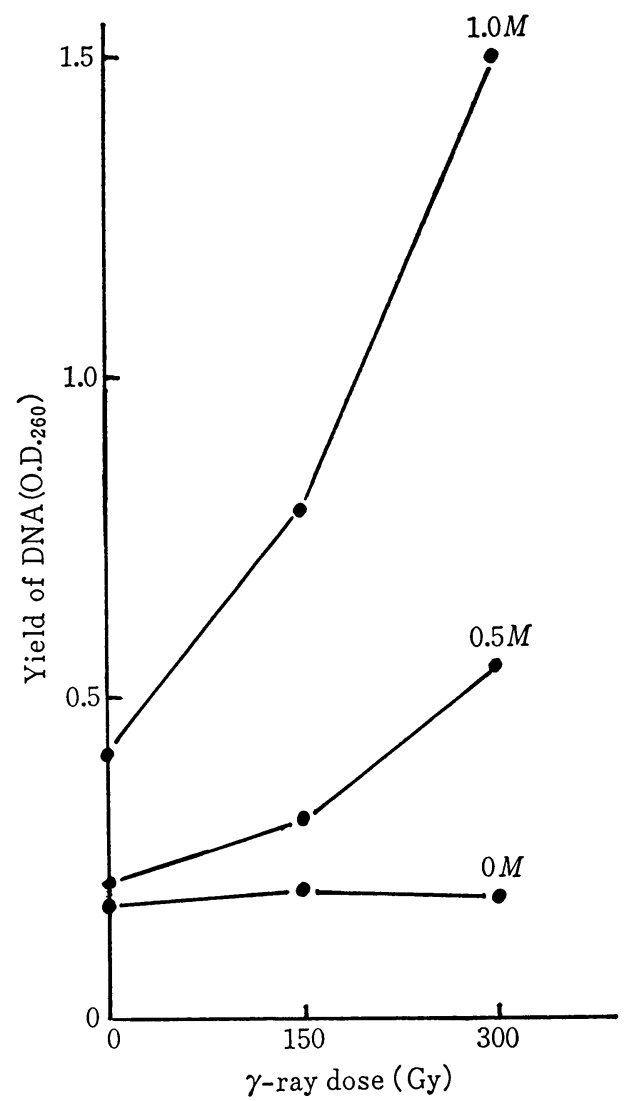

Fig. 3 The yield of macromolecular DNA (by the absorbancy at O.D. $260 \mathrm{~nm}$ ) from $\gamma$-irradiated barley nuclei in the presence of ethylene glycol.

$(1 \mathrm{~Gy}=100 \mathrm{rad})$
$(500 \mathrm{rad}) / \mathrm{min}$ from a source of ${ }^{137} \mathrm{Cs}(4000 \mathrm{Ci})$ of the Research Center for Nuclear Science and Technology, the University of Tokyo. Irradiated nuclei were freezed in dry ice immediately. Macromolecular DNA was extracted from them by the modified Murmar's method ${ }^{2)}$. The macromolecular DNA content was determined by the absorbance of UV $260 \mathrm{~nm}$ and the Burton's method of diphenylamine ${ }^{3)}$.

\section{Results}

Figure 2 shows that yields of the macromolecular DNA are different between the irradiated nuclei and the unirradiated ones. Such difference became greater in the presence of ethylene glycol. The yields from the irradiated nuclei increased quickly with increasing concentration of ethylene glycol, but those from the unirradiat-

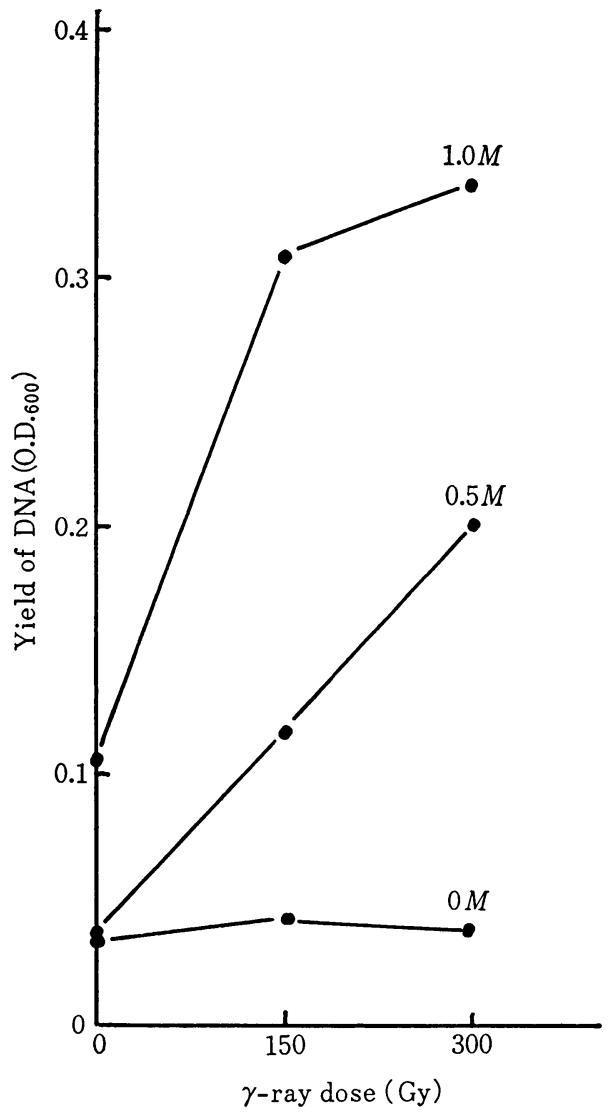

Fig. 4 The yield of macromolecular DNA (by the method of diphenylamine) from $\gamma$-irradiated barley nuclei in the presence of ethylene glycol.

$(1 \mathrm{~Gy}=100 \mathrm{rad})$ 
ed control did slowly. Figure 3 shows the yield of DNA determined by the absorbancy at O.D. (optical density) $260 \mathrm{~nm}$ and Fig. 4 shows measuring of DNA by the method of diphenylamine. Both figures demonstrates that the yields of DNA increase if cell nuclei are irradiated with higher doses in the presence of ethylene glycol. Both figures show similar tendency that, the higher the exposed dose and the concentration of ethylene glycol, the better the yield.

\section{Discussions}

Nakanishi' ${ }^{4}$ has observed by the use of electron microscope that $\gamma$-irradiated chromatin fibers appeared as thinner fibers than the unirradiated and supposed that the DNA fibers unwound and extended. It is also reasonable that the increase of DNA yield might be due to unwind- ing and extending of chromatin fiber by $\gamma$ irradiation, being ready at DNA extraction. As shown in Fig. 3 and 4, the same result in the both methods of determination on DNA excludes the possibility of doubt that different substances from DNA were extracted by $\gamma$-irradiation. In conclusion $\gamma$-radiation dissociated the nucleoprotein coat or induces unpolymerized states of barley chromatin.

\section{References}

1) R. Roots and S. Okada: Radiat. Res., 64, 321 (1975)

2) T. Naito and K. Soda: Bull. Fac. of Agri., Meiji Uni. No. 50, 31 (1980)

3) K. Burton: Biochem. Jour., 62, 315 (1956)

4) Y.H. Nakanishi: Jour. Radiat. Res., 21, 58 (1980) 